\title{
DIE KERK EN GEWELD*
}

\author{
P.H. KAPP, Randse Afrikaanse IIniversileit, Johanneshurg
}

\section{ARSTRAC:T}

For the purposes of this paper the author uses the definition of violence implied by Clausewitz in his definition of war, viz. that the application of violence as a means of forcing your opponent to submit to your will.

The first part of the paper deals with a survey of the changing patterns of thought regarding war and changing altitudes towards war. The survey ranges from the traditionally approving allitude towards war 10 greater stress on pacificsm. It includes writers such as Augustine, Luther and Calvin on the one hand, and lsaiah, Micah and various (hinese authors through to Immanuel Kant on the other hand. He also refers to the impact of the Second World War and the founding of various bodies aimed at creating peace, and the papal encyclicals aimed at the same ideal.

In the second part of the paper altention is given to the changing nature of war and violence. Developments such as conscription, concentration camps and scorched earth policies are discussed. There is reference too to nuclear warfare and the newer development of guerilla warfare.

The author then also points out that there is a cerlain inevilability to be discerend, because in spile of ever-growing pacifistic ideals, wars and revolutions have increased since 1945.

The author then summarizes, on the one hand,justifications for violence and, on the other hand, ju.stifications for pacifism.

The third part of the paper deals with the South African situat ion in particular. There is reference to the role and the altitudes of the Reformed churches and to the South African Conunal of Churches.

The paper is concluded with a statement of certain principles held by the author about the posture of the (hurch when dealing with war and violence.

Die tema van ons gesprek is sodanig geformuleer dat dit alle vorme van geweld insluit en nie net na verskillende vorme van gewapende verset of oorlö̈ verwys nie. Dit sou dus ook geweld in die sin van misdaad, die rol van

- Voordrag gelewer voor Gespreksgroep Kerk-Universiteit, Johanneshurg, 1982.

Koers, 47(3) 1982. 


\section{Kapp}

geweld in die teater, rolprent en televisie kon insluit. Dit sou selfs só wyd opgevat kan word dat dit ook die sg. strukturele geweld behels. Daarmee word bedoel dat 'n bepaalde struktuur - politics, ekonomies - wat vir sekere mense onaanvaarbaar is, deur hulle as 'n stuk geweld beskou word omdat dit hulle dwing om dinge te doen waarmee hulle nie saamstem nie. Ek vertolk egter die onderwerp as die Kerk en die probleem van oorlog en gewelddadige verset wat tot bloedvergieting, verwoesting en ontwrigting van menselewens lei en wat dus die Kerk met sy boodskap van vrede en liefde regstreeks raak. Die soort geweld wat dic onderwerp voor oë het, is stellig dit wat Carl von Clausewitz met sy definisie van oorlog bedoel het, $\mathrm{nl}$. dic aanwending van geweld as 'n middel om jou teenstander te dwing om jou wil te volg.

Dit is so'n omvangryke onderwerp, wat die terrein van die pomelogic en die irenelogie insluit, dat 'n mens voor 'n moeilike opgaaf geplaas word om binne die bestek van so ' $n$ kort referaat icts beduidends by te dra. Dit sal my dus seker nie verkwalik word nie as ek, getrou aan my vakgebied, begin met 'n kort samevatting van die voortdurend veranderende denke oor en die houding jeens geweld en die veranderende aard van geweld as sodanig. In die derde plek wil ek na die besondere Suid-Afrikaanse omstandighede verwys en ten slotte by wyse van 'n aantal stellinge my standpunt as 'n gewone kerklidmaat stel.

\section{VERANDERING IN DIE DENKE OOR GEWELD}

Die voor- en teenstanders van gewcld en oorlog kan hulle elkeen op 'n lang tradisic beroep, maar die oorheersende tema van werke uit die verlede is dié wat in een of ander vorm van geweld of oorlog gocdkcur, ondersteun, aanmoedig of regverdig. Die Ou Testament is nie net vol gegewens oor oorloë nie, maar die krygstaal was ook deel van die alledaagse taal. 'Terwyl die vroegste Christelike kerk aanvanklik'n pasistiese houding ingencem het, soos veral deur Tertullianus ( $\pm 160-220$ ) en Origines ( $\pm 185-254$ ) verwoord, het daar in die vierde eeu met die bekering van Konstantyn (306-337) in 312 'n belangrike verandering ingetree. Met die Sinode van Arles (314) is die weg gebaan vir die ont wikkeling van ' $n$ Christelike regverdiging van oorloë. Hierdie standpunt is uiteindelik die duidelikste deur die kerkvaders Augustinus (354-430) en Thomas Aquinas (1225-1274) verwoord.

Augustinus, wat die verkrummeling van die Romeinse $\mathrm{R}$ yk bcleef het soos o.a. weerspieël in Alarik sc inval in Rome in 410, was die ecrste Christenteoloog wat 'n taamlik breedvocrige standpunt oor oorlog en vrede 


\section{Kerk en geweld}

uitgewerk het (Bainton, 1960:85-100). Hy is veral sterk beïnvloed deur sy gevoel van verantwoordelikheid vir die lot van die wêreld en sy waardering vir en bekommernis oor die Romeinse Ryk, wat die kerk en die regsorde beskerm het. In De civilate Dei $1 / 21$ betoog hy dat doodmaak nie outomaties identies aan moord is nie, en stel hy die standpunt van die regverdige oorlog: "'n oorlog in gehoorsaamheid aan die heilige gebod of in ooreenstemming met Sy gebooie". Regverdige oorloë, sê hy, is voorkomende oorlö̈ (XIX/7). Oorloë mag nooit 'n doel op sigself wees nie maar moet ter wille van die vrede gevoer word. Hy stel drie voorwaardes vir die regverdige oorlog: net 'n wett ige owerheid mag oorlog maak; daar moet ' $n$ juiste oorsaak wees, en die motief moet reg wees. Aquinas het 'n vierde voorwaarde toegevoeg, $\mathrm{nl}$. dat die juiste metode van oorlogvoering (d.w.s. in ooreenstemming met die Christelike gewete) gevolg moet word (Looke, 1965:23).

Maarten Luther het heelwat aandag aan die probleem van oorlog en vrede gegec. In sy $0 b$ Kriegsleute auch in seligem Siande sein können (1526) stcl hy dit dat God die swaard ingestel het om die boosdoeners te straf en die vrede te handhaal. Oorlog is daar om die boosheid te straf, dit is 'n operasioncle ingreep om, net soos 'n geneesheer doen, die oorsaak van die kwaad te verwyder. Wanneer die owerheid onregverdig optree, moet die onderdaan God meer gehoorsaam wees as die owerheid. Hy verwerp'n aanvalsoorlog maar aanvaar 'n regverdige oorlog (Van der Woude, 1966: 104). 'n Oorlog uit magsbegeerte, landhonger, oorbevolking, uitbreidingsdrang of ander ekonomiese motiewe verwerp hy.

Johannes Calvyn (1509-1564) wys in sy Institusie "beroeringe" af maar aanvaar oorlog. Hy beklemtoon dat die onderdaan normaalweg 'n vrome gesindheid "tot die uiterste toc" aan die owerheid verskuldig is, selfs al is dit die "allerslegste tiran", behalwe in een uitsonderingsgeval, nl. dat aan God meer gehoorsaamheid verskuldig is as aan die mens (Sizoo, s.j.:26-32). Op die argument dat daar in die Nuwe Testament geen getuienis te vind is om Christene se dcelname aan oorloè te regverdig nie, antwoord Calvyn (i) dat die oorsake vir oorloë steeds geldig is en dat die owerheid sy onderdane moet beskcrm; (ii) dat dit in die Nuwe Testament om dic geestelike Ryk van Christus gaan en nie om 'n handleiding vir' $n$ burgerlike regering nie (iii) en dat 'n Christen se optrede tydens 'n oorlog selfdissipline, selfbeheersing en menslikheid moet openbaar. Hy moet met 'n swaar hart dic oorlog tegemoet gaan wetende dat dit ' $n$ gruwel is wat deur menslike boosheid veroorsaak is. Dit is op grond van hierdic uitsprake dat skrywers oordcel dat Calvyn nie net 'n teenstander van kernoorlog sou wees nie maar dat hy vandag 'n aktiewe pasifis sou wees (Wallace, 1959:174). 


\section{Kapp}

Hugo de Groot (1583-1645), die groot Nederlandse regsgelecrde, het probeer om dcur dic skepping van 'n volkereg oorlog te voorkom, te beheer en te begrens. Hy het Christene aangemoedig om nie aan oorlog deel te neem nie maar liet dic bestaan van 'n regverdige oorlog erken (Looke, 1965:195-206).

Morcle besware teen oorlog en die totale verwerping van geweld dateer van oudsher af. Jesaja en Miga (Israel in die 8ste ceu v.C.), Boeddha (Indië, 6de ceu v.C), Lau-tse en Mo Ti (Sjina, 5 de eeu v.C.) het reeds geweld in beginsel verwerp. Talle denkers en skrywers het hierna daarteen standpunt ingenecm, maar hulle standpunte het nêrens ernstige wcerklank gevind nie. Immanuel Kant (1724-1804) se Zum Ewigen Frieden word deur sommige skrywers as die cerste ware irenologiese geskrif beskou (Hecring, 1953:108). Kant was geen absolute pasifis nie, want hy ken wel aan oorlog 'n plek toe. Maar hy voorsien dat wanneer' $n$ streng morele regsbasis die fondament van die samclewing vorm, oorlog nie meer sal voorkom nie, omdat die reg oor alles wat in botsing met die wette van die rede is, sal beslis.

Die verwoesting van die Tweede Wêreldoorlog en die mag van die atoombom en die NBCG-wapens (nukleêre, biologiese, chemiese, en geofisiese wapens) het aan die pasifisme die geleentheid gebied om veel sterker as ooit tevore na vore te tree. Die atoombom, sê. Hecring, het nie net Japan geskud nie maar die kerk en die hele wêrcld.

In vergelyking met die stemme wat ná 1945 opgegaan het, en die organisasies en instansies wat hulle energie ingespan het om alle oorlog te beëindig, was dit wat voor die Tweede Wêreldoorlog gebeur het, 'n druppel in die emmer. Ten spyte van die Haagse Konferensie van 1899, die Volkebond se pogings om oorlog te bekamp, die idealistiese KelloggBriandverdrag van 1928 en die groot Ontwapeningskonferensie van 1931 het dic Twecde Wêreldoorlog uitgebreek.

Die VVO het deur UNESCO in 1974 sy sg. Tensions Project geloods. Met behulp van die Sielkunde is deur studic en navorsing gepoog om die diepste oorsake van konflik in die gees van die mens na te spoor. In baie lande is ook vredesnavorsingsinstitute en vredesbewegings gestig, soos die Pax Christibeweging in Frankryk in 1944, die Rooms-Katolicke Wêrelduredesbond (1953), die Pugwashbcweging wat deur kernfisici begin is, dic World Association of World Federalists, Het Gereformeerde Vredesberaad en Kerk en Vrede (binne die Nederlandse Hervormde Kerk). Die geskiedenis ken natuurlik ook 'n aantal vredeskerke wat ver in die geskicdenis teruggaan. Die 


\section{Kerk en geweld}

bekendstes is stellig die Anabapt iste (gestig in die $16 \mathrm{de}$ eeu), die K wakers ( 1650 gestig) en dic Broedergemeente (18de ecu).

In 1948 het die Wêreldraad van Kerke oorlog veroordeel as in stryd met Gods wil en weicring om aan enige oorlog deel te neem as 'n wettige en eerbiedwaardige standpunt aanvaar. Tog is daarvoor voorsiening gemaak dat 'n Christen aan 'n verdedigingsoorlog as die minste van twee euwels mag deelneem. In daaropvolgende uitsprake het die pasifisme steeds sterker geword. 'I'og is by Uppsala (1968) aanvaar dat revolusionêre verandering wcl deur gewcld kan geskied. Daarom dat besluit is om finansiële steun aan versetbewegings te verleen.

In 1963 het pous Johannes XXIII in sy ensikliek Pacem Interris oorlog bestempel as 'n skending van alle deur God geskape natuurorde. Pous Paulus VI het in Populorum Progressio (1967) die leer van die regverdige oorlog afgewys.

Die Gereformeerde Ekumeniese Sinode het vcel minder aandag aan hierdie saak gegee. Tussen 1946 (Grand Rapids) en Sydney (1972) is die oorlogsprobleem net een keer bespreek, nl. op Potchefstroom (1958). Wapengeweld is nie as ontoelaat baar afgekeur nie, en daar is verklaar dat alhoewel dit nie in die Bybelse sin as sonde bestempel kan word nie, "behoort oorlog in elk geval tot die Sondeorde, en gaan daar gewoonlik veel sonde mee gepaard. Daarom mag geen poging gespaar word nie om dit te verhoed" (Acta, 1958:28-29).

Die Gereformeerde Kerk in Nederland het die oorlogsvraagstuk besonder versigtig benader, en tot 1970 was daar nog geen duidelike besluit oor die saak genecm nie hocwel binne die GKN Het Gereformeerd Vredesheraad gestig is. Die Nederlandse Hervormde Kerk het reeds in 1952 'n baie kritiese standpunt teen kernbewapening geneem maar dit in 1964 gekwalifiseer as'n afwysing van die gebruik en nie die besit van kernwapens nie (vgl. NHK, 1963; NHK, 1964).

In Suid-Afrika het daar van die kant van die $\Lambda$ frikaanse Kerke nog min besinning oor die vraagstuk van oorlog en vrede plaasgevind. Tydens die Tweede Vryheidsoorlog het predikante, teoloè en lidmate aan die oorlog deelgeneem en het die Kerke dié optrede goedgckeur en die reg tol gewapende verset teen ' $n$ imperialistiese moondheid aanvaar. Met die Rebellie van 1914 is die wettige reg tot verset erken, sonder om 'n spesifieke uitspraak oor dic Rebcllie te lewer. 


\section{Kapp}

Die Gereformecrde Kerk het op sy Sinode van 1961 die Gereformecrde Ekumeniese Sinode van 1958 se uitsprake oor dic oorlogvraagstuk onderskryl, met die weglating van die sinsnede "die opbou van 'n internasionale regsorde". Partikuliere sinodes van die Gereformeerde Kerk het hulle sterk uitgespreek teen die Wêreldraad van Kerke se besluit om geld aan terroristebewegings in Suider-Afrika te skenk omdat dit tot oortreding van die sesde gebod kon lei.

Die Algemene Sinode van die Nederduitse Gereformeerde Kerk het in 1970 die "vryheidsbewegings" geag as synde "in stryd met die eis van gehoorsaamheid aan die Heilige Skrif en die voorbeeld van Jesus Christ us wat aan Sy volgelinge die duidelike opdrag gegee het om te ly onder vermeende, of werklike onreg, ecrder as om dit aan ander aan te doen deur onder andere gewelddadige optrede en verset". Die reg tot opstand is dus blykbaar prinsipiecl ontken.

\section{DIE VERANDERENDE AARD VAN OORLOG}

Twee sake verdien eerste die aandag. Watter soorte geweld of oorlog kom voor en wat is die algemene oorsake van oorloë? Polemologiese navorsers gebruik verskillende klassifikasies van oorloë, wat in so 'n kort referaat nie bchandel kan word nie. Daarom is dit net nodig om die vernaamste soorte oorlog wat vir ons dag van belang is, te beklemtoon. Dic beperkte oorlog tussen twee of meer magte met 'n spesificke doel voor oë is die algemeenste en word ook gewoonlik as 'n konvensionele oorlog bestempel. 'n Algemene oorlog is iets wat plaasvind wanneer 'n groot aantal strydmagte betrokke raak soos in die stryd teen Napolcon en die Eerste en die Tweede Wêreldoorlog. Tot en met die neëntiende eeu was hierdie twee soorte oorloè in werklikheid professionele oorloë gevoer tussen professionele lec̈rs en is die gewone burgery weinig daardeur geraak, gewoonlik net wanneer stede beleër is.

Met die instelling van konskripsie (diensdwang) in Frankryk in 1793, wat die ecrste keer deur Napoleon behoorlik toegcpas is, is ' $n$ clement toegevoeg wat sou meebring dat die gewone man al hoe meer by oorlog betrokke geraak het. Die ontwikkeling van die strategie om die leërs tot oorgawe te dwing deur die gewone burgery te betrek, hetsy deur hulle in konsentrasiekampc te plaas, hetsy deur bestaansmoontlikhede met 'n verskrocideaardebcleid te verswak, het aan 'n oorlog 'n nuwc en verskrikkende betckenis gegee. Die ontwikkeling van docltreffender aanvalswapens en lugaanvalle het van die verskrocide-aardebeleid ' $n$ beleid van verwoeste 


\section{Kerk en geweld}

stede gemaak. Uiteindelik het langafstand- behcerde missiele, kernwapens, die waterstof- en ncutronbom en biologiese en chemiese wapens 'n skrikwekkende nuwe oorlog geskep: die totale oorlog. Daarmee word bedoel dat nie net ' $n$ aanvalsteiken nie maar ' $n$ hele land in enkele aanvalle vernietig kan word. Indien byvoorbeeld 'n superwaterstofbom van 10 megaton op 'n plek afgegooi sou word, sou 'n lugdrukgolf ontstaan met totale vernietiging tot 6 kilometer, crnstige skade tot 13 kilometer en ligte skade to 26 kilometer. Hittebestraling sal vir verdere skade tot 55 kilometer verantwoordelik wees, en radioaktiewe decltjies sal trefkrag hê oor 'n afstand van 700 tot 1000 kilometer (DeKam e.a., 1969:3-12).

Hoewel die vierde vorm van oorlog - die guerillatipe oorlog - nie iets is wat in ons tyd ontstaan het nie, is dit 'n vorm van stryd wat vandag op grootskaal, veral in die Derde Wêreld, voorkom. Konvensioncle konfrontasie met trocpe word vermy, en daar word op die tref-en-trapmetode gekonsentreer. Burgerlike teikens met die doel om die grootste moontlike verleentheid vir ' $n$ regering te veroorsaak, vrees, angs en onrus by die gewone bevolking te saai en om publisiteit vir hulle "saak" te verkry, is die algemene oogmerke. Gewone terrorisme, wat dieselfde ten doel het, is hierby ingesluit. Hierdie vorm van geweld is niks anders as onverklaarde oorlog nie en kan net plaasvind as die aanvallers iewers basisse bekom vanwaar hulle kan opereer. Hierdie soort van geweld word geregverdig op grond van die argument dat dit in die meeste gevalle vir die beoefenaars onmoontlik is om hulle wil langs ander weë te laat seëvier. Die bekendste voorbeclde is die optrede van die lerse Republikeinse Leër, die Rooi Brigade, Arabiese terroristeorganisasies, die Sandinistaopstand wat Nicaragua verower het, die stryd in San Salvador en die stryd op ons eie grense. Dit word graag as nasionalistiese bevrydingstryde voorgestel, terwyl die aanspraak dal dit suiwer Kommunistiese pogings is om die bewind oor te neem, ontken word. In werklikheid is dit pogings om die bestaande orde geheel en al omver te werp en 'n nuwe sosioëkonomiese orde te skep. Gevolglik vind die voorstanders van hierdie strewe maklik aansluiting by die Kommunisme, word hulle maklik deur 'n handjievol Kommuniste gemanipuleer en kom hulle uitcindelik nie net in die greep van dic Kommuniste nie maar word hulle maklik deur een van die Kommunistiese magte onder die vleuels geneem. Hoewel 'n mens die aanwesigheid van 'n vryheidsideaal nie kan ontken nic, is dit 'n vryheidsideaal met 'n duidelike kleur en is of word dit aan Marxistiese magstrewes vasgcketting. Dit is te verklaar uit die feit dat hicrdie soort verset 'n sterk sosioèkonomiese basis het wat veel makliker by sosialistiese en Marxistiesc bewegings en ideale aansluiting vind as by enige 


\section{Kapp}

ander. Die Kommuniste het 'n strategie vir hierdie soort geweld ontwikkel wat hulle in staat stel om veel beter as enige ander groep aansluiting te vind.

Guerilla-oorlog en konvensionele oorlog kom sedert 1945 vry algemeen voor ten spyte van die feit dat pasifisme sterker verkondig word as ooit vantevore. Tussen 1946 en 1965 is dertig sodanige oorloë gevoer, waarvan enkeles - Kashmir 1947, Israel en Arabiese lande 1948, Indo-Sjina 1947-1954, die Sjinese Burgeroorlog 1949, die Koreaanse Oorlog 1950-1953 c.a. - elk die lewc van meer as 100,000 mense geëis het. 'Twaalf van hierdie oorloë was as gevolg van Kommunistiese bedrywighede, vier was rewolusies, twaalf koloniale bevrydingsoorloë met ' $n$ Marxistiese inslag en in nege gevalle het aansprake op grondgebied en gesag 'n groot rol gespeel. Drie van hierdie oorloë was in Europa, vier in Latyns-Amerika, ses in Afrika en sewentien in Asië.

By wyse van 'n samevatting kan gesê word dat die argumente ten gunstc van oorlog op die volgende neerkom:

- Dit is 'n onvermydelike deel van die mens se gebroke en verlore toestand. Ewige vrede veronderstel 'n volmaakte wêreld.

- Dit is 'n noodsaaklike magsmiddel om probleme "op te los" of ten minste 'n belangrike wending te gee.

- Dit is 'n noodwendige deel van die "struggle for existence and revival of the fittest".

- Stryd, spanning, swaarkry en lyding is vir die mens noodsaaklik om hom in staat te stel om in hierdie wêreld 'n sinvolle lewe te lei. Daarsonder sal die mens tot 'n swakkeling verval of sal hy homself so verhoog en verheerlik dat hy vir God geen plek het nie. Oorlog bring die slegste maar ook die beste in 'n mens na vore. Dit dien dus ook 'n kreatiewe doel.

- Oorlog en geweld is 'n deel van God se strafgerig oor die wêreld. Die gclowige moet dit as sodanig aanvaar en daarna strewe om sy geloof ten spyte van oorlog en geweld te verdiep.

Aan die ander kant berus die pasifistiese verwerping van geweld op die volgende oorweginge (kyk Van Wyk, J.H., 1974):

- Die Bibliologiese mot ief. Oorlog en geweld word in heelparty teksverse in die Ou en Nuwe Testament veroordeel.

- Die Christologiese motief. Christus is nie net vir die gelowige van belang vanweë sy reddingsboodskap nie, maar ook sy persoonlike optrede moet nagcvolg word. Groot klem word gelê op sy verwerping van geweld $\mathrm{en}$ die 


\section{Kerk en geweld}

feit dat Hy nooit die swaard aangewend het of Hom daarop beroep het nic. - Dic Ekklesiologiese moticf. Die kcrk is 'n st igting van God en as sodanig'n vredesinstrument, en die boodskap wat hy verkondig, mag nooit iets anders as ' $n$ vredesboodskap wees nic.

- Die Eskatologiese motief. Die einddae behels nie die oorwinning van dic magtc van geweld nie maar dic triomf van die vrede.

- Eties-rasionele motief. Oorlog en geweld word nie net op etiese gronde as ontmensing verwerp nie maar ook op 'n hele aanial rasionele gronde as 'n irrasionele poging om probleme "op te los". In werklikheid word vecl meer probleme geskep as wat opgelos word.

- Juridiese motief. Dit is mag en nie reg wat seëvier nie, en dit is onskuldiges wat die swaarste ly.

- Politokologiese motief. Interne en eksterne weerbaarheid deur middel van 'n polisiemag is vir die pasifiste aanvaarbaar, maar militarisme as 'n faktor in staatsbeleid vir watter doel ook al word totaal verwerp.

\section{DIE BESONDERE SITUASIE MET BETREKKING TOT SUID-AFRIKA}

Daar is reeds op die amptelike standpunte van die Afrikaanse Kerke met betrekking tot die kwessie van geweld gewys. Hierdie probleem het met dic grociende dekoloniseringsproses in $\Lambda$ frika en die ontwikkcling van magtc wat 'n revolusionêre anti-kolonialistiese vryheidstryd tcen Suid-Afrika voorstaan, vir ons van aktucle belang geword. Veral sedert 1974 het daar binne cn buite Suid-Afrika al hoe sterker stemme opgegaan wat gewcld bepleit om die Blankebewind in Suid-Afrika omver te werp. SWAPO se optrede en Suid-Afrika se betrokkenheid daarby word as die beginfase van so 'n vryheidstryd gesien.

In Januarie 1970 het die Wêreldraad van Kerke (WRK) sy bekende Programme to (ombat Racism (PCR) in werking gestel, wat ten doel gehad het om die bevryding van "onderdrukte" rasse te bevorder. Hieruit het die hulpprogramme - finansieel en anders - aan terroristeorganisasies in Suider-Afrika voortgevloei. Die WRK het sy optrede geregverdig deur te verklaar dat die maatskaplike orde in Suid-Afrika op mag en geweld berus ('n standpunt wat deur die SARK ondersteun is) en dat dit daarom geregverdig is om dit met 'n gewapende stryd te beveg (De Gruchy, 1979:129-140). Die SARK het hom nie met die besluit om geldelike steun aan terroristeorganisasics te verleen, verenig nie.

In 1974 is 'n verdere dimensie tot die houding van sommige kerke 


\section{Kapp}

betreffende geweld gevocg toe die SARK tydens sy jaarlikse konferensie te Hammanskraal sy Resolution on conscientious objection aanvaar het.

In die voorwoord van hierdie dokument is verklaar dat die vraagstuk van vrede in Suid-Afrika in geregtigheid wortel, en geregtigheid word vertolk as die wil van God "(to) set at liberty those who are oppresscd" (Luk. 4: 18). Dit word gestel dat "the Republic of South $\Lambda$ frica is at present a fundamentally unjust and discriminatory society" en daarom verantwoordelik gehou moet word vir die feit dat die vrede in Suid-Afrika bedreig word. Omdat "the military forces of our country are being prepared to defend this unjust and discriminatory society" en omdat die gelowige God eerder as dic mens moet gehoorsaam, moet die stelsel van institusionele geweld teengestaan word en mag die Christen nie militêre diensplig as sy onbevraagtekende plig beskou nie. Daar is ook besluit om op lidkerke 'n beroep te doen om hulle houding t.o.v. militêre kapelane in heroorweging te neem "and to investigate the state of pastoral care available to the communicants at present in exile or under arms beyond our borders and to scek ways and means of ensuring that such pastoral care may be properly exercised" (Ecunews, 1974:6). In opvolging van hierdie besluit is op sinodes van Engelstalige Kerke in 1976 en 1977 konsensus bereik dat kapelane aangewys móét word maar dat ook vir die bediening van die terroriste voorsiening gemaak moet word (De Gruchy, 1979: 146-147).

\section{ENKELE BEGINSELSTANDPUNTE}

In die lig van bogenoemde gegewens en vertolk teen die agtergrond van die geskiedenis wil ek graag my referaat afsluit met 'n poging om by wyse van 'n aantal stellings tot eie standpuntinname te kom.

- Die pasifisme wat sedert 1945 in kerklike kringe herlcef, is eerder deur die konkrete militêre feite geïnspireer as wat dit op Bybelse gronde gebaseer is. Dit is voorts ook sterk selektief t.o.v. 'n konsekwente houding tcenoor geweld. Dit blyk veral uit die feit dat hulle sosiale en ekonomiese geregt igheid as eis vir die voorkoming van geweld stel, sonder om enigsins'n begrip vir die werklikhede van histories geworde situasies te openbaar.

- Terwyl die Christelike verantwoordelikheid van kerk, staat en individu om vir mense 'n redelike lewensbestaan te skep nooit ontken mag word nie, is die aandrang op politieke, sosiale en ckonomiese geregtigheid 'n eis wat deur die politicke stryd van die dag eerder as die Heilige Skrif geïnspireer is. Dit is naamlik deur die sosialisties-Marxist iese samelewingskritiek geskep en gedefinieer en word nou deur teoloë vanuit die Heilige Skrif as 'n kruistog 
gevoer. Hulle hoop om daardeur vir die kerk aansien te verwerf. Mense se behoeftes aan politieke, maatskaplike en eknomiese geregtigheid word te maklik as verskoning vir louheid van geloof en werke aanvaar.

- Die kerk se bemoeienis met politieke formules is een van die gevaarlikste tendense in die hedendaagse kerklewe. Wat maak een formule Christeliker as ' $n$ ander? Die towerformule van meerderheidsmag kan net so maklik in 'n tirannic van getalle ontaard, en wat is Christclik daaraan? Is dit Christelik om mense met behulp van die moderne middele en media te manipuleer en met beloftes van ' $n$ absolute regenerasie tot bepaalde politieke aksies aan te vuur?

- Hoe ons ook al geweld of oorlog klassifiseer, in sy wortel gaan dit om mag of, soos ck Von Clausewitz in die begin aangehaal het, om jou wil te laat seëvier. Die terroristestryd teen Suid-Afrika is nie 'n stryd primêr om reg en geregtigheid nie maar om mag. So 'n stryd kan nie met mooi praatijies tcengestaan word nie maar moet met doeltreffende militêre mag en strategic vroegtydig en doeltreffend bekamp word. Hakkejagoperasies is geregverdig om die stryd tot 'n einde te probeer bring.

- Die geskiedenis leer my dat oorlog nooit sal verdwyn nie. Dit is geen Catalisme wat strydig is met die Christelike hoop en geloof nie, maar 'n realisme. As gelowiges behoort ons nie daarom te sê dat die vredes- en liefdesboodskap dus niks vir ons wêreld te sê het nie. Ons moet leef en werk in die oortuiging dat hierdic wêreld ten spyte van jammerlike leed onder die bestuur staan van 'n wyse, heilige en almagtige God, wat deur die stryd heen die vrede najaag en deur die toorn heen sy liefde openbaar.

- Edmund Burke het reeds gesê: "All that is necessary for the spread of evil is that good men do nothing". En "good men" kan in hierdie wêreld niks vermag as hulle nie ook uit 'n posisie van militêre sterkte en paraatheid die bose magte kan afskrik of in bedwang hou nie. Wee dic kerk as die heer van die huis eendag terugkom en daar moet verantwoording oor talente gedoen word en al wat hy kan sê, is ons het só na vrede gesoek dat ons maar die talent om die ware te verdedig begrawe het.

- Patriotisme is nie die oorsaak van oorloè nic. Daarom is ware volks- en vaderlandsliefde geen struikelblok vir die kerk of dic Christen nie. Trouens, die Christen kan juis beter volksdienaar en vaderlander wees omdat hy die reddende liefde van God ken en die betekenis daarvan vir daardie verband ook kan aantoon.

- Wat het geword van die Christen se plig tot sorg en aanvaarding en berusting as dit nou as sy plig gestel word om utopiesc idecs van absolute reg en geregtigheid na te jaag?

- Ons moet voortdurend die plig van Christelike sorg ecrder as politieke en sosiökonomiese formules in ons benadering van vraagstukke vooropstel. 


\section{Kapp}

Christelike sorg is minder absolutisties, maak nie verwaande aansprake nie en mislei nie.

- Dic Christelike kerk moet die nie-Christelike magte van hierdie wêreld vreesloos tegemoetgaan in die wete dat die ont moetingsterrein as'n roeping tot redding en nie as die terrein van die maatskaplike kritiek gedefinieer moct word nie.

- Die Christelike kerk moet hom afvra wat hy wil bereik deur die wil tot weerstand deur middel van aanhoudende kritick op militêre diensplig af te breek. Is hy besig om God se saak te dien of dien hy die magte van chaos, vernietiging en godloosheid?

- Die kcrk moct as alternatief vir geweld voortdurend die bereidheid tot gesprek, onderhandeling en hervorming beklemtoon. As die staat nie bereid is om na hierdie boodskap te luister nie, kan hy nie die morele steun van die kerk verwag nic. Maar die kerk moet ook nic die pad van onderhandeling en hervorming as 'n plaasvervanger vir die neem en uiteindelike uitvoer van besluite beskou nie. As die staat onderhandel het en sy bereidheid tot hervorming te kenne gegce het, bly dit nog sy finale verantwoordelikheid om besluite te ncem en dit uit te voer al sou dit nie almal ewe veel tevrede stel nie.

- Die kerk moet sorg dat die plek en rol van die militêre mag beperk bly tot dié van verdediger en beskermer en nie dié van politieke en staatsmag word nie. Die lec̈r moet basies vredeslec̈r wees, moet hom ten volle vir Gods Woord oopstel en sy hele bestuur en optrede voortdurend aan God se voorskrifte meet. Daartoe moet die kerk hom help.

- Ons eie weermag het met sy 80-20-beleid in die operasionele gebied getoon hoe 'n vredesleär mense kan help deur onderwys, ekonomiese hulpverlening, gesondheidsdienstc en pogings tot die algemene verbetering van hulle lewenstandaard.

- Terrorisme is 'n gewetenlose middel om dic mag in die hande te kry. Hulle spits hulle op burgerlike teikens toe sonder om die gevolge van hulle optrede of die belange van die burgerlike bevolking in ag te neem. Terrorisme vind nie plaas omdat daar geen bereidheid van state se kant is om politieke en sosiaal-ckonomiese probleme op te los nie, maar omdat die oplossings wat wel aangebied word vir hulle onaanvaarbaar is. Dit bring hulle nie aan bewind nie en plaas die magsmiddele nie in hulle hande nie. Wat in Zimbabwe gebeur het, is 'n enkele voorbeeld van hoe dié proses verloop. Daarom mag die Kerk hom nooit met hierdie bewegings vereenselwig nie en moet hulle ten sterkste veroordeel word. Wanneer die Kerk in watter vorm ookal hierdie bewegings steun, is hy nie aan die kant van 
Christclike gercgtigheid nie, maar is hy aan die kant van 'n bepaalde magsformule wat weinig met geregtigheid te maak het.

\section{BIBLIOGRAFIE}

ACTA van die vierde Gereformeerde Ekumeniese Sinode te Potchefstroom, 1958:28-29.

BAINTON, Roland H. 1960. Christian attitudes toward war and peace. Nashville: $\Lambda$ bingdon.

DE GRUCHY, John, W. 1979. The church struggle in South Africa. Kaapstad: David Philip.

DE KAM, P. e.a. 1969. Oorlog en vrede. Utrecht: Dekker en Van de Vcgt. ECUNEWS, 5.8.1974.

HEFRING, G.J. 1953. De zondeval van het Ghristendom. Utrecht: Bijleveld.

NEDERLANDSE HERVORMDE KERK (NHK). 1963. Het vraagstuk van de kernwapenen. 's Gravenhage: Boekencentrum.

NEDERLANDSE HERVORMDE KERK (NKH). 1964. Woord en Wederwoord. 's Gravenhage: Boekencentrum.

SIZOO, A. s.j. Institutie of onderwijzing in de Christelijke godsdienst IV, XX. Delft.

TOOKE, J.D. 1965. The just war in Aquinas and Grotius. London: S.D.C.K.

VAN DER WOUDE, C. 1966. Het oorlogsprobleem in de tijd der Reformatie in Christendom en oorlog. Kampen: Kok.

VAN WYK, J.H. 1974. Etick van vrede. (Proefskrif, PU vir CHO.)

WALI,ACE, R.S. 1959. Calvin's doctrine of the Christian life. Grand Rapids: Eerdemans. 